\title{
Chemical and isotopic compositions of boron in the geothermal waters in the Xianshuihe Fault Zone, Western Sichuan Province, China
}

\author{
Jianfei Yuan ${ }^{1,}$, Fen $\mathrm{Xu}^{2}$, and Huizhong Liu ${ }^{1}$ \\ ${ }^{1}$ Chengdu Center, China Geological Survey, Chengdu 610081, Sichuan, China \\ ${ }^{2}$ State Key Laboratory of Geohazard Prevention and Geoenvironment Protection, Chengdu University of Technology, Chengdu \\ 610059, China
}

\begin{abstract}
In this study, boron contents and boron isotopic compositions of geothermal waters are first reported in the Xianshuihe Fault Zone (XSHFZ), Western Sichuan. The results show that boron contents of geothermal water are $0.03-10.50 \mathrm{mg} / \mathrm{L}$, and the $\delta^{11} \mathrm{~B}$ values range from -6.75 to $4.01 \%$, indicating the non-marine origin. The $\delta^{11} \mathrm{~B}$ values and $\mathrm{Cl} / \mathrm{B}$ molar ratios reveal that boron in geothermal water is mainly leached from reservoir rocks, such as carbonate and igneous rocks. Comparing it with other geothermal systems in the Yunnan-Tibet Geothermal Belt, we found that the samples from XSHF have the largest variations of $\mathrm{Cl} / \mathrm{B}$ molar ratio and the intermediate $\delta^{11} \mathrm{~B}$ values.
\end{abstract}

\section{Introduction}

The Xianshuihe Fault Zone (XSHFZ), having produced frequently strong earthquakes, is one of the most active faults in the world [1]. A large number of hot springs occur along the XSHFZ and its secondary fault zones [2]. Several previous studies have reported the chemical and isotopic characteristics of geothermal waters in part of the XSHFZ [3-5]. In those documents, high boron concentrations were found in geothermal waters, but little work has been done on the geochemistry of boron as well as its isotope.

In this study, the boron contents and boron isotopic ratios of geothermal waters, sampled from the XSHFZ, were determined to understand the geochemical behavior and their source characteristics.

\section{Geological setting}

The study area is located in Western Sichuan Province (Fig.1). The area is a part of the Songpan-Ganzi Fold belt, which is generally $4000 \mathrm{~m}$ above the sea level with its peak higher than $7000 \mathrm{~m}$ (Konga Mountain) [2]. The Songpan-Ganzi fold belt is comprised by numerous lithospheric-scale strike-slip

fault zones and magmatic rocks. Triassic strata composed of primarily sandstone, siltstone, slate, and limestone are widely distributed, while Permian and other strata are sporadic [1].

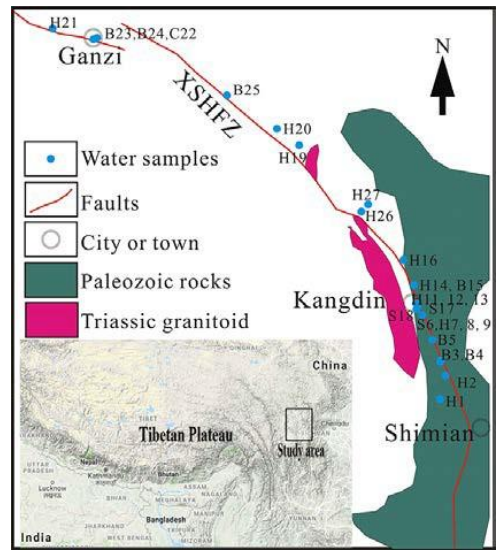

Fig. 1. Geological map of the study area and Location of water samples along the XSHFZ.

\footnotetext{
* Corresponding author: jianfeiyuan@163.com
} 


\section{Sampling and analytical methods}

Twenty-seven samples, including hot springs, geothermal well water, groundwater and stream water, were collected in the XSHFZ in April of 2017. When sampling, all water samples were filtrated through a $0.45 \mu \mathrm{m}$ filter in situ, and then stored in new $500 \mathrm{ml}$ polyethylene bottles that had been rinsed by deionized water twice before sampling.

Unstable parameters including water temperature $(\mathrm{T})$ and $\mathrm{pH}$ were measured in the field. Boron, silica, and chloride concentrations were determined using ICP-AES and IC in the State Key Laboratory of Biogeology and Environmental Geology, China University of Geoscience (Wuhan). Boron isotope ratios were analyzed in Beijing Research Institute of Uranium Geology, using positive thermal ionization mass spectrometry and expressed conventionally in relation to the NIST SRM 951 boric acid reference material. The data are reported as $\delta^{11} \mathrm{~B}$ value.

\section{Results and discussion}

The chemical-physical parameters, including $\mathrm{T}, \mathrm{pH}, \mathrm{Cl}, \mathrm{B}, \delta^{11} \mathrm{~B}$, and $\mathrm{Cl} / \mathrm{B}$ molar ratios, for groundwater, stream water, and geothermal water samples are listed in Table 1 . The $\mathrm{pH}$ values of the geothermal water are 6.43-8.94, while that of groundwater and stream water are 7.83, and 6.88-8.15, respectively. The discharge temperatures of geothermal water are between 39 and $85{ }^{\circ} \mathrm{C}$, which are higher than that of cold waters (range from 7 to $19{ }^{\circ} \mathrm{C}$ ). $\mathrm{SiO}_{2}$ contents in thermal waters range from 40.2 to $429 \mathrm{mg} / \mathrm{L}$ (except sample H21, which is mixed by cold groundwater), showing a good relationship with the discharge temperature.

Table 1. Partial analyses of water samples collected in the XSHFZ. na: not analyzed; nd: not detected.

\begin{tabular}{|c|c|c|c|c|c|c|c|c|}
\hline No & Water Type & $\begin{array}{c}\mathrm{T} \\
\left({ }^{\circ} \mathrm{C}\right)\end{array}$ & $\mathrm{pH}$ & $\begin{array}{c}\mathrm{SiO}_{2} \\
(\mathrm{mg} / \mathrm{L})\end{array}$ & $\begin{array}{c}\mathrm{Cl} \\
(\mathrm{mg} / \mathrm{L})\end{array}$ & $\begin{array}{c}\text { B } \\
(\mathrm{mg} / \mathrm{L})\end{array}$ & $\mathrm{Cl} / \mathrm{B}$ & $\begin{array}{l}\delta^{11} \mathrm{~B} \\
(\%)\end{array}$ \\
\hline $\mathrm{C} 22$ & Groundwater & 16 & 7.83 & 7.5 & 4.4 & 0.02 & 86.7 & na \\
\hline S6 & Stream water & 7 & 8.02 & 7.0 & 3.2 & 0.01 & 96.7 & -5.81 \\
\hline S17 & Stream water & 8 & 6.88 & 7.9 & 3.4 & nd & & na \\
\hline S18 & Stream water & 19 & 8.15 & 12.5 & 4.4 & nd & & na \\
\hline H1 & Hot spring & 39 & 6.97 & 40.2 & 6.3 & 0.21 & 9.3 & -6.75 \\
\hline $\mathrm{H} 2$ & Hot spring & 53 & 8.11 & 62.1 & 227 & 4.26 & 16.2 & 0.89 \\
\hline H7 & Hot spring & 81 & 7.49 & 169 & 227 & 3.12 & 22.1 & -4.6 \\
\hline H8 & Hot spring & 69 & 6.68 & 162 & 192 & 2.71 & 21.6 & na \\
\hline H10 & Hot spring & 58 & 7.54 & 131 & 134 & 2.07 & 19.7 & -5.93 \\
\hline H11 & Hot spring & 63 & 7.13 & 124 & 138 & 2.05 & 20.5 & na \\
\hline H12 & Hot spring & 55 & 7.77 & 164 & 376 & 5.45 & 21.0 & -3.85 \\
\hline H14 & Hot spring & 45 & 6.43 & 48.9 & 43.4 & 0.67 & 19.7 & na \\
\hline H16 & Hot spring & 49 & 7.27 & 122 & 81.2 & 0.96 & 25.8 & na \\
\hline H19 & Hot spring & 45 & 6.9 & 44.6 & 12.0 & 3.31 & 1.10 & -2.95 \\
\hline $\mathrm{H} 20$ & Hot spring & 55 & 6.96 & 49.7 & 4.7 & 1.32 & 1.09 & -1.96 \\
\hline $\mathrm{H} 21$ & Hot spring & 55 & 7.71 & 11.2 & 3.7 & 0.03 & 44.3 & -4.64 \\
\hline $\mathrm{H} 26$ & Hot spring & 74 & 7.12 & 117 & 35.5 & 2.31 & 4.66 & -2.89 \\
\hline $\mathrm{H} 27$ & Hot spring & 38 & 6.59 & 49.0 & 30.7 & 2.50 & 3.75 & na \\
\hline B3 & Geothermal well & 59 & 6.83 & 69.2 & 20.0 & 0.47 & 12.9 & 4.01 \\
\hline B4 & Geothermal well & 48 & 7.10 & 59.3 & 15.5 & 0.34 & 13.8 & na \\
\hline B5 & Geothermal well & 50 & 7.25 & 46.7 & 109 & 0.68 & 48.5 & -0.09 \\
\hline B23 & Geothermal well & 85 & 7.82 & 129 & 10.9 & 5.94 & 0.56 & -4.05 \\
\hline B13 & Geothermal well & 68 & 7.41 & 100 & 237 & 3.59 & 20.1 & -6.32 \\
\hline B15 & Geothermal well & 51 & 6.86 & 59.9 & 93.3 & 1.22 & 23.2 & -2.61 \\
\hline B24 & Geothermal well & 64 & 6.85 & 50.5 & 6.9 & 2.64 & 0.80 & -3.43 \\
\hline B25 & Geothermal well & 40 & 6.91 & 96.2 & 8.5 & 1.61 & 1.60 & -0.61 \\
\hline D9 & Geothermal well & 63 & 8.94 & 429 & 612 & 10.5 & 17.8 & -3.69 \\
\hline
\end{tabular}




\subsection{Boron concentrations and boron isotopes}

The boron concentrations of groundwater and geothermal waters are $0.02 \mathrm{mg} / \mathrm{L}$, and 0.03 to $10.5 \mathrm{mg} / \mathrm{L}$, respectively (Table 1). It is obvious that boron is much more enriched in geothermal water than in cold groundwater. Moreover, the boron content of geothermal water from deep well (D9) is higher than those from hot springs (samples coded with " $\mathrm{H}$ ") and shallow wells (coded with "B").

The $\delta^{11} \mathrm{~B}$ values of geothermal waters range from -6.76 to $4.01 \%$, with an average of $-2.91 \%$ (Table 1 ). In contrast, the stream water is more depleted in boron isotope than most of geothermal waters.

\subsection{Origin of boron}

The major recharge source for hot springs and geothermal well water is meteoric water. However, due to their very low boron contents, neither cold groundwater (sample C22), snow-melting water (sample S6), nor local precipitation should be the main source for boron of geothermal water in the XSHFZ.

The $\mathrm{Cl} / \mathrm{B}$ molar ratios and $\delta^{11} \mathrm{~B}$ values of the geothermal waters are much lower than those of seawater $(\mathrm{Cl} / \mathrm{B}=1273$; $\delta^{11} \mathrm{~B}=39 \%$ ) and typical geothermal waters of marine origin [6]. So there is no-marine origin for geothermal waters in the XSHFZ. Boron can be easily released from different types of rocks during water-rock interactions [6-7]. The reservoir rocks of geothermal systems in the XSHFZ are marine carbonate, sandyslate, and granite [1]. The $\delta^{11} \mathrm{~B}$ values of geothermal waters fall into the scope of those for marine carbonate rocks $\left(\delta^{11} \mathrm{~B}\right.$ : -5.5 to $20 \%$ o and igneous rocks $\left(\delta^{11} \mathrm{~B}:-17\right.$ to $-2 \%$ ) [6-7], which reveals that the interactions between geothermal waters and reservoir rocks are main source of their boron contents.

\subsection{Comparison with other geothermal systems in the Yunan-Tibet geothermal belt}

The geothermal system of western Sichuan is a part of the Yunan-Tibet geothermal belt [2]. It is well known that there are high $\mathrm{B}$ and $\mathrm{Cl}$ contents in geothermal waters in the Yunan-Tibet geothermal belt [6-7]. Yuan et al. [6] and Lu et al. [7] have studied the chemical and isotopic composition of B in geothermal waters in those area. Are there any similar geochemical characteristics of B between the XSHFZ geothermal system and the Yunan-Tibet geothermal belt? In order to answer this question, a comparative study of B and its isotope in geothermal waters in XSHFZ and Yunnan-Tibet geothermal belt is carried out in the following paragraph.

The $\mathrm{Cl} / \mathrm{B}$ molar ratios and $\delta^{11} \mathrm{~B}$ values in the other geothermal systems of the Yunan-Tibet geothermal belt (especially in the Southern Tibet and Western Yunnan Province) are from 0.1 to 13.6, and -16 to $13.1 \%$, respectively [7]. Furthermore, there is a positive correlation between $\mathrm{Cl} / \mathrm{B}$ and $\delta^{11} \mathrm{~B}$ values (Fig.2). In contrast, geothermal waters in the XSHFZ show large $\mathrm{Cl} / \mathrm{B}$ variations with molar ratios ranging from 0.56 to 48.5 , while that for $\delta^{11} \mathrm{~B}$ values are relatively constant. The distinct chemical and isotopic compositions of B in thermal waters between the XSHFZ and the Yunan-Tibet geothermal belt might be controlled by wall rock types, geothermal structures and magmatic activity, detailed discussion will be illustrated in other paper.

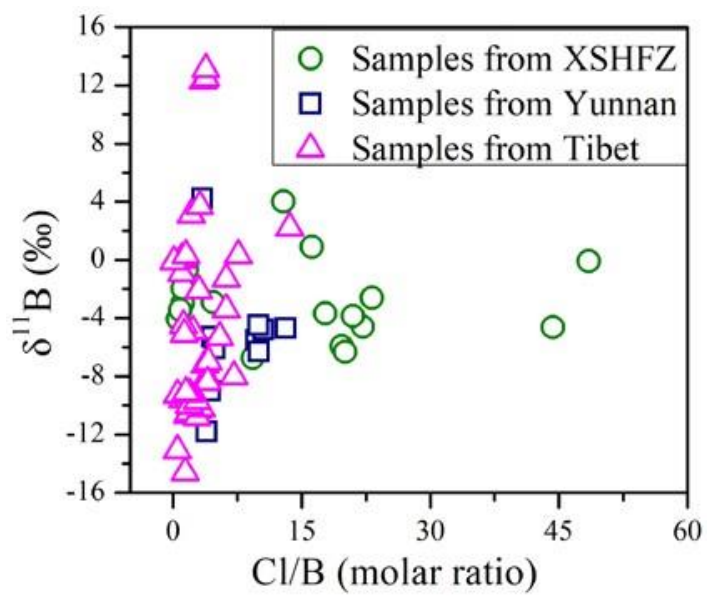

Fig. 2. $\delta^{11} \mathrm{~B}-\mathrm{Cl} / \mathrm{B}$ relationship for the geothermal systems in the Yunnan-Tiebet geothermal belt (including the XSHFZ of Western Sichuan Province).

\section{Conclusions}

This work presented the chemical and isotopic compositions of boron in geothermal waters in the XSHFZ. The boron concentrations, $\mathrm{Cl} / \mathrm{B}$ molar ratios and $\delta^{11} \mathrm{~B}$ values are from 0.03 to $10.50 \mathrm{mg} / \mathrm{L}, 0.56$ to 48.51 , and -6.76 to $4.01 \%$, respectively. Furthermore, the $\mathrm{Cl} / \mathrm{B}$ molar ratios and $\delta^{11} \mathrm{~B}$ values of the geothermal waters indicate that the interactions 
between geothermal waters and the reservoir rocks are the main source of their boron contents. In addition, there are large variations of $\mathrm{Cl} / \mathrm{B}$ ratio and constant $\delta^{11} \mathrm{~B}$ values compared to geothermal waters in the Yunnan-Tibet geothermal belt.

This study was financially supported by the National Natural Science Foundation of China (Grant No. 41502245), the Science and Technology Foundation of Chengdu Center, China Geological Survey (Grant No. KJ201867). We gratefully acknowledge Y. Kharaka for kind editorial handling and Pro. Z.H. Pang, and another anonymous referee for constructive reviews and suggestions, which significantly improved the manuscript.

\section{References}

1. X. Tang, Z. Pang, S. Hu, J. Tian, S. Bao. Tectonophysics, 717 (2017)

2. J. Zhang, W. Li, X. Tang, J. Tian, Y. Wang, Q. Guo, Z. Pang. Sci China-Earth Sci, 60, 8(2017)

3. Q. Guo, Z. Pang, Y. Wang, J. Tian. Appl Geochem, 81 (2017)

4. J. Luo, Z. Pang, Y. Kong, Y. Wang. Environ Earth Sci, 76, 9 (2017)

5. Z. Shi, F. Liao, G. Wang, Q. Xu, W. Mu, X. Sun. Geofluids, (2017)

6. J. Yuan, Q. Guo, Y. Wang. J. Geochem Explor, 140 (2014)

7. Y. Lu, M. Zheng, P. Zhao, R. Xu, Sci China-Earth Sci, 57, 12 (2014) 